\title{
Estimation of elevated black carbon episode over Ukraine using Enviro-HIRLAM
}

\author{
Mykhailo Savenets ${ }^{1}$, Larysa Pysarenko ${ }^{1}$, Svitlana Krakovska ${ }^{1}$, Alexander Mahura ${ }^{2}$ and Tuukka Petäjä ${ }^{2}$ \\ ${ }^{1}$ Ukrainian Hydrometeorological Institute (UHMI), Kyiv, 03028, Ukraine \\ $5 \quad{ }^{2}$ Institute for Atmospheric and Earth System Research (INAR), Faculty of Science, Physics / University of Helsinki (UHEL), \\ Helsinki, 00560, Finland
}

Correspondence to: Mykhailo Savenets (savenets@uhmi.org.ua), Alexander Mahura (alexander.mahura@ helsinki.fi)

\begin{abstract}
Biomass burning is one of the biggest sources of black carbon concentrations which negatively impacts human health and contribute to climate forcing. In this work we explore horizontal and vertical variability of black carbon concentrations over Ukraine during a wildfire episode in August 2010. Using Enviro-HIRLAM modelling framework the black carbon atmospheric transport was modelled for coarse and accumulation mode aerosol particles emitted by the wildfire. Elevated pollution levels were observed within the boundary layer. The influence of the black carbon emissions by the wildfire was identified up to $550 \mathrm{hPa}$ level and at distances of about $2000 \mathrm{~km}$ from the fire areas. Strong temperature inversions at nighttime resulted in subsiding air mass movement and lead to increased concentrations of black carbon in the atmospheric

15 boundary layer. Ground-based measurements of dust showed increase of concentration up to $73 \%$ in comparison to average values. The fingerprint of local fires was found in the areas with local maxima of summary black carbon values for coarse mode. The findings of the case study could help to understand the behaviour of black carbon distribution during anticyclonic conditions which often observed in mid-latitudes in the summer and lead to wildfires occurrence.
\end{abstract}

\section{Introduction}

20 "Black carbon (BC) is the component of fine particulate matter (PM2.5) considered as one of the contributors to climate forcing next to carbon dioxide (Bond et al., 2013, Kurganskiy et al., 2015) and highly probable harmful health impact (Janssen et al., 2011; WHO, 2012; O’Dell et al., 2020)". "BC is formed as a product after incomplete combustion of biomass and fossil fuels (e.g., Forbes et al, 2006, Bond et al., 2013)". "Large amount of BC is emitted into the atmosphere from biomass burning (Konovalov et al., 2018) as a part of total chemical species flux during wildfires (Amiro et al., 2001; Barnaba et al., 2011;

25 Virkkula et al. 2014a), which cause elevated pollution levels around burned areas (e.g. Virkkula et al. 2014b; Wu et al., 2018; Castagna et al., 2021)". "BC content and different aerosol constituents in case of huge emission frequently estimated by using atmospheric modelling (Hodzic et al., 2007; Bessagnet et al., 2008; Konovalov et al., 2018; Singh et al., 2018; Magalhaes et al., 2019; Kostrykin et al., 2021) and sometimes in-situ measurements (Yttri et al., 2007; Eleftheriadis et al., 2009; Singh et al., 2018; Jia et al., 2021)". In Ukraine, there are no observations for carbonaceous aerosols in the atmosphere. "Moreover, only few studies have mentioned about Ukrainian territory and BC distribution during wildfire events (Pavese et al., 2002; 
Yang et al., 2017)". Considering the gap in knowledge of BC distribution over Ukraine and some ongoing problems with its modelling capacities and emission inventories, this study aims to analyse temporal and three-dimensional spatial scales of BC distribution after wildfire emissions in case of unfavourable weather conditions leading to elevated pollution episodes that are frequently observed on the Ukrainian territory.

As a starting point for the current case study, the forest fire events occurred in summer 2010 at the center of the European territory of Russia with strong wildfire emissions. These emissions supported by extremely hot weather and rainless conditions. "Several studies discussed different aspects of this event, including aerosol distribution (Galytska et al., 2010; Konovalov et al., 2011; Witte et al., 2011; Galytska et al., 2016), radiative effects (Chubanova et al., 2012) and air temperature changes (Pere et al., 2014)". "The emissions were detected and influenced atmospheric composition in Finland as well (Leino et al., 2014)". "The most severe period was connected with the August fires with a lot of pollution transported towards Ukraine (Galytska et al., 2016) and it ended after 18th August when the pollution levels returned to typical for these geographical regions (Witte et al., 2011)".

45 “In more detail, Galytska et al. (2018) focused on analysis of summer 2010 wildfires' events and on studying aerosol content changes for period 1 July - 20 August 2010”. This study used satellite data from the Moderate Resolution Imaging Spectrometer (MODIS) and the Cloud-Aerosol Lidar with Orthogonal Polarization (CALIOP) for detecting burned areas, aerosols' vertical profiles and clouds. Data from ground-based sun photometers of AErosol RObotic NETwork (AERONET), measuring column-integrated aerosol optical depth (AOD), were validated against the satellite measurements. The HYbrid

50 Single-Particle Lagrangian Integrated Trajectory (HYSPLIT) model was used to simulate air mass backward trajectories (with vertical levels of $0.5,1.5,3,4$ and $5 \mathrm{~km}$ ), and analysis of meteorological situation and air masses transport were performed with help of a series of synoptic maps. The maximum AOD above Moscow (Russia) on 7th August was associated with airflows from the central part of Russia at levels of $0.5-1.5 \mathrm{~km}$ passing through fire areas. In Kyiv, the maximum AOD was registered on 15th August (up to $4 \mathrm{~km}$ level) with air movements from the forest fire regions. The simulated air trajectories referred to anticyclonic movements in both cases. These conditions facilitated stagnation of air and accumulation of pollutants in the region of interest. In Sevastopol, the maximum AOD was observed on 16th August within the layer 0.5-5 km due to air masses transport from the territory of active fires.

"Spatiotemporal distribution of trace gases and aerosol at the ground level was analysed by Konovalov et al. 2011". "The total $60 \mathrm{CO}, \mathrm{PM} 10$ and $\mathrm{O}_{3}$ concentrations were analysed using satellite measurements and the CHIMERE chemistry transport model (Konovalov et al., 2011) with the most attention to the Moscow region”. It was found that extremely high levels of daily mean $\mathrm{CO}$ and PM10 concentrations reached 10 and $700 \mu \mathrm{g} / \mathrm{m} 3$ respectively. $\mathrm{O}_{3}$ concentrations were episodically very large (up to $400 \mu \mathrm{g} / \mathrm{m}^{3}$ ) even after emission significantly decreased. It was estimated that approximately $10 \mathrm{Tg} \mathrm{CO}$ were emitted in the Moscow region during the 2010 heat wave (more than $85 \%$ of the total annual anthropogenic CO emissions). "Aerosol, emitted 
65 from summer 2010 wildfires caused shortwave direct radiative effects (Pere et al., 2014)". Significant reduction of diurnal average solar radiation was found to be at the ground and up to $80-150 \mathrm{~W} / \mathrm{m} 2$. The resulting feedbacks lead to a cooling of the air up to $1.6^{\circ} \mathrm{C}$ at the surface and up to $0.1^{\circ} \mathrm{C}$ at altitudes of $1.5-2.0 \mathrm{~km}$.

We explored the BC concentrations in Ukraine during the intensive biomass burning episodes in the region in August 2010.

70 We deployed Environment - High Resolution Limited Area Model (Enviro-HIRLAM) modelling system in the analysis. "It is a fully online coupled (integrated) numerical weather prediction (NWP) and atmospheric chemical transport (ACT) modelling system for research and forecasting of meteorological, chemical and biological weather (Baklanov et al., 2017)”. These simulations will help us to understand temporal and spatial BC distribution after wildfire emissions in case of summer anticyclonic conditions leading to frequent wildfires occurrence in mid-latitudes and resulted elevated pollution levels. Here

75 we initialized a case study was carried out for elevated pollution episodes in August 2010 over Ukrainian territory caused by atmospheric pollution transport from the severe forest fires occurred in central part of Russia. BC concentration and its distribution were estimated for extended period 2-18 August 2010 considering the extreme pollution episode lasted 7-17 August 2010. Analyses were conducted for both the accumulation and coarse modes as their particle sizes tend to collect in the lowest atmospheric layers and mostly could have influence on human health.

\section{Data and methods}

\subsection{Enviro-HIRLAM setup}

"The Enviro-HIRLAM system consists of two main blocks. The HIRLAM model itself as a NWP model, which could be used for research and operational purposes (HIRLAM-5 Scientific Documentation, 2002)". The Enviro-components are integrated into the NWP model. These components include a variety of atmospheric chemistry schemes, which simulate tropospheric

85 sulphur cycle chemistry, gas-phase chemistry, photolysis rates, heterogeneous chemistry, aerosol formation and dynamics, its wet and dry deposition, different feedback mechanisms (direct, semi-direct, indirect). "For modelling of fluxes of BC the Enviro-HIRLAM has been already used for the Northern Europe and Arctic regions (Kurganskiy et al., 2015; Nuterman et al., 2015)".

90 The model domain for runs covers almost all the European territory and it is enlarged for considering the atmospheric circulation in the middle latitudes. It consists of 500x400 grids along longitude vs. latitude. It has $15-\mathrm{km}$ horizontal resolution and time step of $120 \mathrm{sec}$. The area of interest is within $20-45^{\circ} \mathrm{E}$ and $40-60^{\circ} \mathrm{N}$ (Fig. 1). Generated model output is saved at every $3 \mathrm{~h}$ interval. 


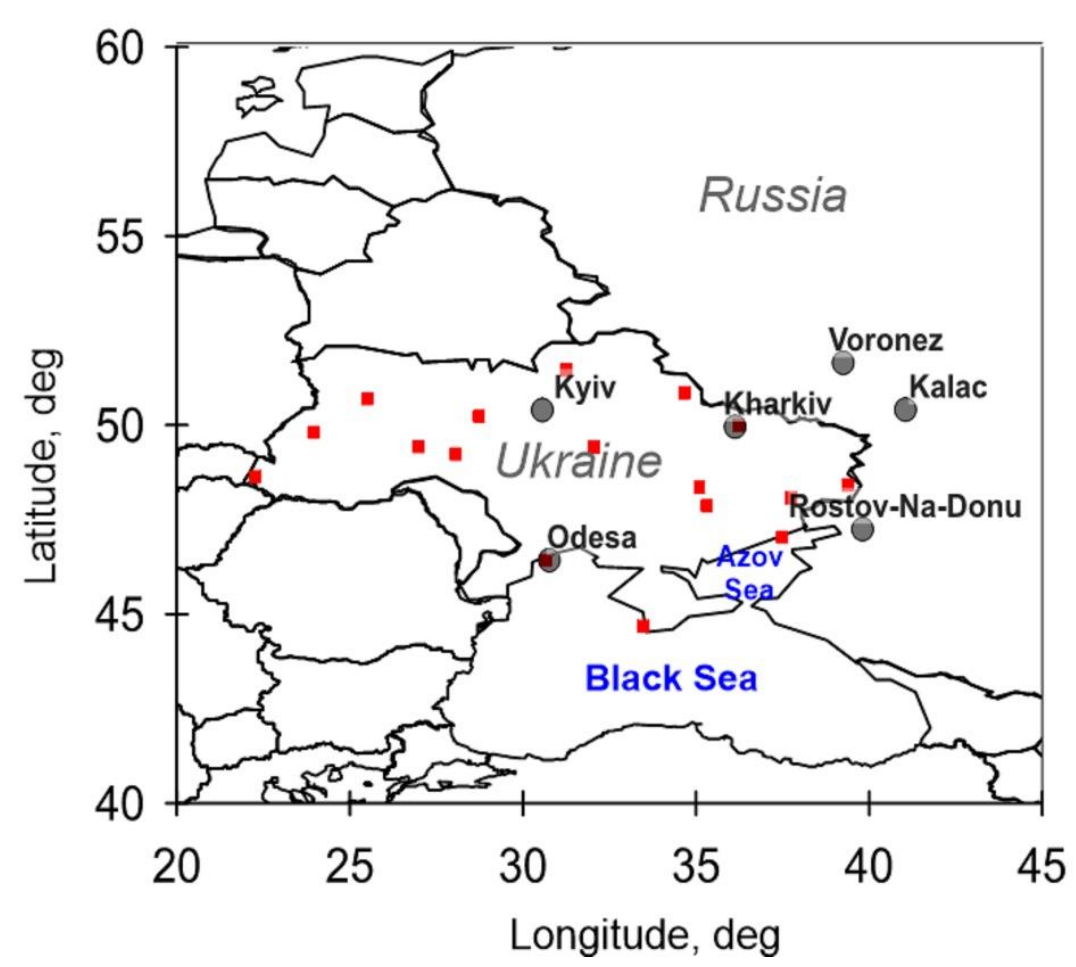

95 Figure 1: The area of interest and locations (black dots) of the radiosoundings stations (Kyiv, Odesa, Kharkiv, Voronezh, Rostovna-Donu, Kalac) and locations (red squares) of air pollution monitoring stations used in this study.

The vertical structure includes 40 model levels with more detailed resolution in the boundary layer. In general, main weatherforming layer (i.e., up to $500 \mathrm{hPa}$ ) includes 22 model levels. This provides a great opportunity for studying the BC vertical transport. The model was run as the following: at first, the reference (or control) run and then, the run with direct aerosol effect included. However, for the purpose of the BC spatio-temporal analysis during severe forest fire episode (7-17 August 2010) we decided to use the output of only a reference run.

The spatial analysis of modelling results was carried out considering all grid cells without spatial averaging and interpolation. It allowed detecting concentrations changes within each grid caused by anticyclonic air movements. Evaluation of accumulated $\mathrm{BC}$ impact was performed by time integration of concentration for studied period. Therefore, the summed values represent the total amount (for both the accumulation and coarse modes) transported by air movements through grid cells.

\subsection{Additional data for analysis}

The mass concentration of dust in PM10 size fraction is only aerosol species that are measured at 129 monitoring sites in

110 Ukraine. "These measurements contain all coarse aerosol particles regardless of their origin (Nadtochii et al., 2019)". Therefore, it is complex to compare accurately results with ground-based measurements. The Ukrainian air pollution 
monitoring network was established several decades ago, and under continuous development and expansion. Therefore, majority of the monitoring sites are situated in cities. Such cities have large number of anthropogenic sources such as factories, thermal power stations, roads, etc. Hence, it is reasonable to use daily averaging and to calculate integral value for each city

115 based on several monitoring stations. Such approach can improve signal-to-noise ratio in a time series. In our study, dust mass concentration data was selected from year 2010 in 20 Ukrainian cities, which are approximately geographically equally distributed within the country. It was done for purposes of intercomparison between western-eastern-southern-northern territories.

120 The upper air soundings data from the Wyoming University database (http://weather.uwyo.edu/upperair/sounding.html) were used to detect temperature inversions. The air temperature vertical profiles were analyzed for 2-18 August 2010 at the following soundings stations: Kyiv (station code 33345), Kharkiv (34300), Odesa (33837), Rostov-na-Donu (34731), Kalac (34247) and Voronezh (34122). Voronezh and Kalac are situated near the areas where the forest fires occurred. Kharkiv and Rostov-na-Donu were selected for estimation of inversion impact at some distance from the fires. Kyiv and Odesa were chosen as relatively distant to sources of the emissions. The temperature vertical profiles were taken into consideration up to 3-3.5 $\mathrm{km}$ above the ground surface at 00 UTC times during the studied period.

Note, that different additional fire related emissions of local origin could also take place. These can influence the observed levels of the BC concentrations in the lowest layer near the surface. "For that, we used the Global Fire Emissions Database

130 (GFED4) (Giglio et al., 2013) from which analysis of burned areas was made". This database has a spatial resolution of $0.25^{\circ} \times 0.25^{\circ}$ of latitude vs. longitude. The burning fraction selected for August 2010 represented the fraction of the burned area within $0.25^{\circ} \times 0.25^{\circ}$ cell.

\section{Results and discussion}

\subsection{Synoptic weather situation during summer 2010 in Ukraine}

According to the Climate Forecast System (CFS) Reanalysis (source: www.wetterzentrale.de) of the $500 \mathrm{hPa}$ geopotential maps over Europe, the blocking anticyclone, which caused severe hot weather, lack of precipitation and occurrence of wildfires, lasted from the end of June to the second half of August 2010 over the East Europe and south-western regions of Russia (see example Fig. 2). Hot air masses from Central Asia penetrated into the north-west, and anticyclone was detected

140 throughout the whole troposphere before the highest pollution levels distributed out of burning cells. Continuous extreme weather and clear sky conditions together with highest insolation in the middle latitudes caused domination of high temperature and low humidity regimes. These were the most favorable conditions for drought formation that played crucial role in emerging fires and their rapid distribution. 
500hPa Geopotential (gpdam), Bodendruck (hPa)

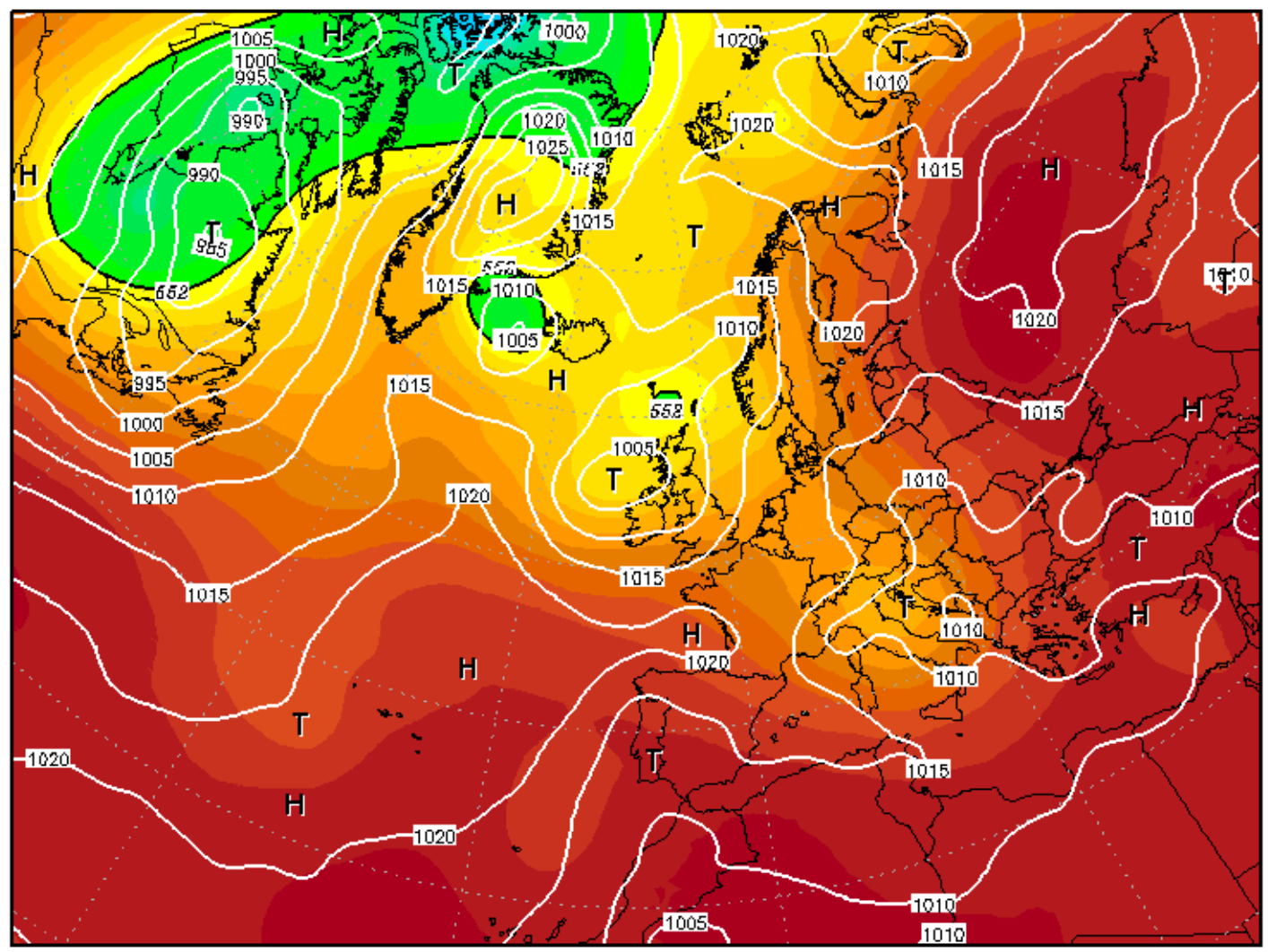

Daten: CF5 Reanalysis

(C) Wetterzentrale

www. wetterzentrale.de

Figure 2. $500 \mathrm{hPa}$ geopotential over Europe on 6th August 2010 (source: www.wetterzentrale.de)

\subsection{Dispersion of wildfire emissions}

The main source of wildfire emissions was located outside of the Ukraine's territory and consisted of several burning areas (see Fig. 3b). Observed anticyclonic conditions influenced on formation and development of spatio-temporal patterns for BC atmospheric transport and dispersion. The time-series for each grid point consist of two maxima. These are connected with observed dominated atmospheric circulation patterns. Typical clockwise air movement for anticyclones in the Northern Hemisphere caused intensive atmospheric transport towards Ukraine during two episodes: 7-8 and 13-16 August 2010. For these episodes, elevated concentrations were also observed in the northern regions of Ukraine (as shown in Fig. 3). 

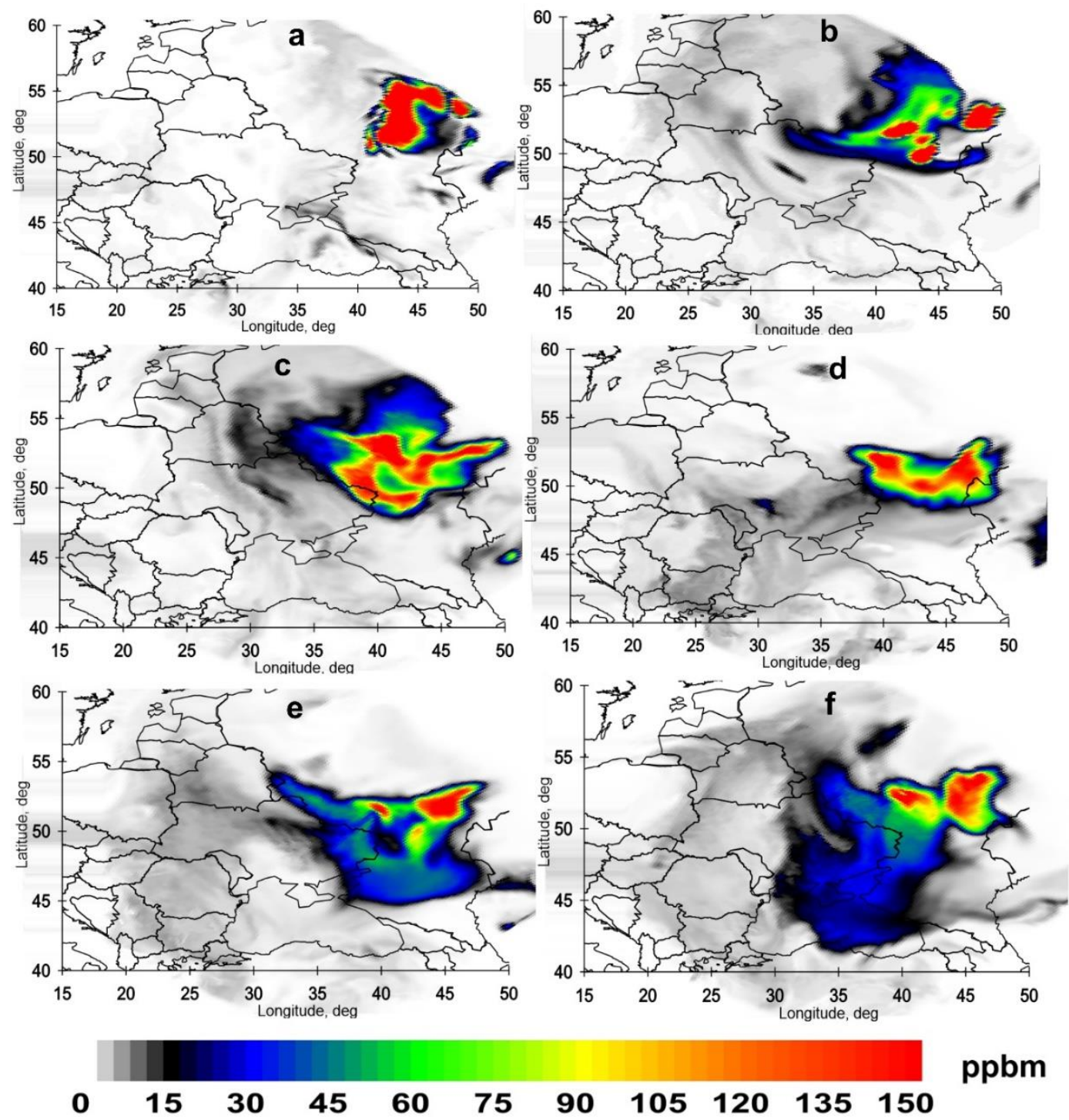

Figure 3: The spatial distribution of the $\mathrm{BC}$ (for the accumulation mode) during the episodes of its highest concentrations at the near-surface level in the days of air movement towards Ukraine at: 00 UTC on 3rd August (a), 18 UTC on 7th August (b), and at 06 UTCs on 8th August (c), 13th (d), 14th (e), 15th (f).

For those days the highest values for BC (accumulation mode) in the boundary layer exceeded 400-600 ppbm near the burning cells and 70-150 ppbm over the selected territories of eastern, central and northern parts of Ukraine. For coarse mode, these values were 300-450 ppbm and 50-80 ppbm for the same territories, respectively. Due to burning cell's location, maxima in time series shifted from the east and north-east to the west and south-west regions of Ukraine. The shifting period depended on anticyclonic air masses movement. Nevertheless, during 7-8 and 13-16 August, the higher values in the western part of 
165 Ukraine were observed within $24 \mathrm{~h}$ after maxima emerged on the east. During unfavorable circulation conditions, the BC plumes were transported and dispersed at distances more than $2000 \mathrm{~km}$ away from the original burned areas. The dominated hot and dry weather conditions interrupted in the second half of August 2010. It occurred when blocking anticyclone weakened and cyclone arrived from the western sector.

\subsection{Diurnal variability of $\mathrm{BC}$ in the region}

During 3-18 August at nighttimes the whole European territory of Russia, central and eastern territories of Ukraine were characterized by presence of surface air temperature inversions. Therefore, it is well seen through BC diurnal variations in the lowest 500-meter layer. The deepest and strongest (up to $655 \mathrm{~m}$ depth and up to $12.5^{\circ} \mathrm{C}$ ) inversions were observed during $4-7$ and on 16 August (see Fig. 4). At $500 \mathrm{~m}$ level the air temperature was warmer by $10-12^{\circ} \mathrm{C}$ than at $2 \mathrm{~m}$. For other nights the inversions were weaker with an average difference of $3-4^{\circ} \mathrm{C}$ in the $2-500 \mathrm{~m}$ layer.
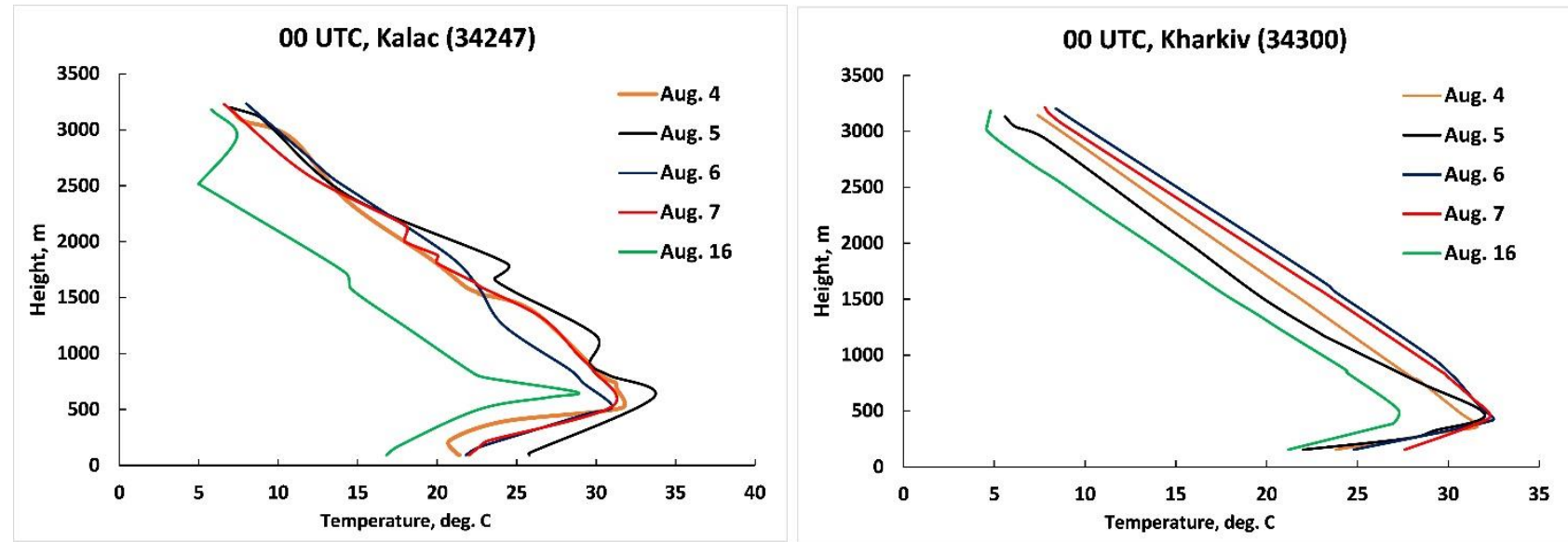

Figure 4: The air temperature vertical profiles from the vertical sounding stations Kalac and Kharkiv for selected dates (4-7 and 16 August 2010) with the deepest surface temperature inversions at nighttime (00 UTC).

In our study, diurnal variations of BC content in the boundary layer were well detected. Maxima more often were observed at night and morning hours, whereas daytime pollution levels in the lower troposphere were low. These diurnal variations appeared due to radiative surface cooling on summer nights, and especially in case of blocking anticyclones. Such anticyclones cause forming of air temperature surface inversions. Together with intensification of downward air movement at nighttimes, $\mathrm{BC}$ from the whole lower and middle tropospheric levels is accumulated within the boundary layer reaching elevated values there. During daytime, the processes of less intensive air descending and turbulence increasing are resulted in more homogeneous vertical distribution. Hence, it can lead to decrease of near-surface BC content. As it happened throughout the Ukraine's territory with anticyclonic weather, BC spatial distribution at the separate level in the lower troposphere looks more 
with dominating horizontal dispersion. This may cause confusion about physical reasons of observed diurnal changes. In the middle troposphere any diurnal variations of $\mathrm{BC}$ content are negligible because surface inversions do not reach these altitudes. The vertical distribution of $\mathrm{BC}$ particles was well detected in the lowest 3-km layer with the maximum observed in the boundary layer. Approximately at $700 \mathrm{hPa}$ level, BC concentration for both accumulation and coarse modes started to decrease very rapidly (Fig. 5). The levels of $630 \mathrm{hPa}$ for the coarse mode and $590 \mathrm{hPa}$ for the accumulation mode were identified as the highest altitudes where the influence of wildfire emissions was detected constantly during daytime. Rarely, during the midday elevated BC concentrations were detected at $590 \mathrm{hPa}$ (for the coarse mode) and at $550 \mathrm{hPa}$ (for the accumulation mode)
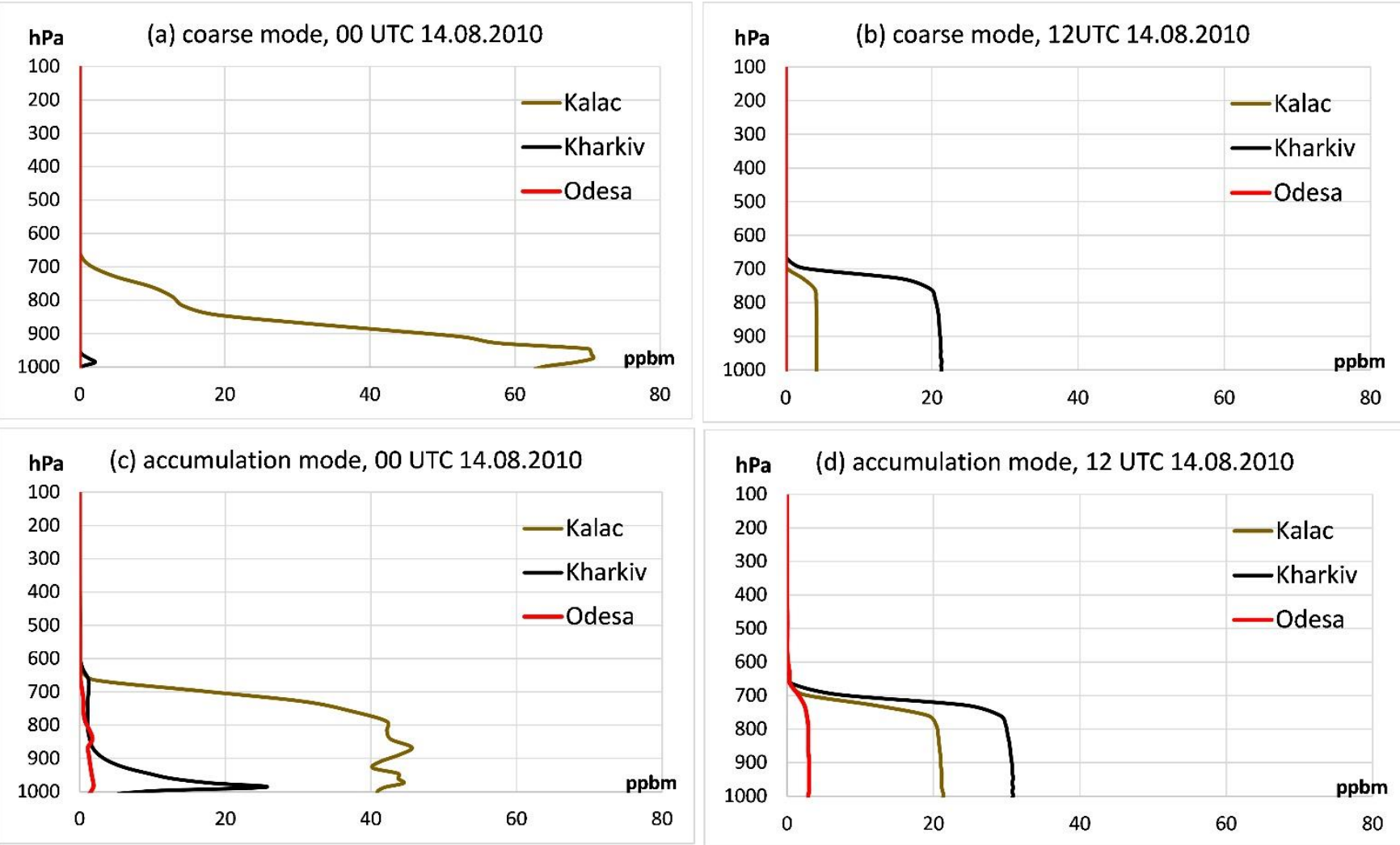

Figure 5: BC vertical profiles for coarse (a,b) and accumulation (c,d) modes over Kalac, Kharkiv and Odesa at 00UTC $(a, c)$ and 12UTC (b,d) on 14th August.

200 It is well seen from the fig. 5 that BC rather equally distributed in the 1000-700 hPa layer during day hours. But at nightime, $\mathrm{BC}$ was observed mostly in the boundary layer, especially the coarse mode. Temperature inversions and air descending during night hours caused more intense coarse mode deposition, therefore it is hard to find coarse particles at the distance more than $1000 \mathrm{~km}$ out from the active fires (represented by Odesa at fig. 5). However, accumulation mode could be transported at such long distances and the transportation was observed at the lower 3-km layer. 


\subsection{Spatial variability in $\mathrm{BC}$ in Ukraine during the wildfire episode}

In general, the wildfire emissions have large accumulative effect in the near-surface layer. Total accumulated amount of BC for the period 3-18 August 2010 reached 13500 ppbm (for accumulation mode) and 2200 ppbm (coarse mode) in the lower tropospheric layer near the burning areas/ cells (Fig. 6). A large amount of combustion products was transported through the atmosphere to the south-west and deposited over territories of the Eastern Ukraine, the Azov and Black Seas. The integral values of $\mathrm{BC}$ on these territories exceeded 800 and $150 \mathrm{ppbm}$ for accumulation and coarse modes, respectively. This is well seen from Fig. 6 where the regions were affected by intensive deposition processes. Due to smaller sizes of the particles, the accumulation mode has larger spatial coverage than the coarse mode.
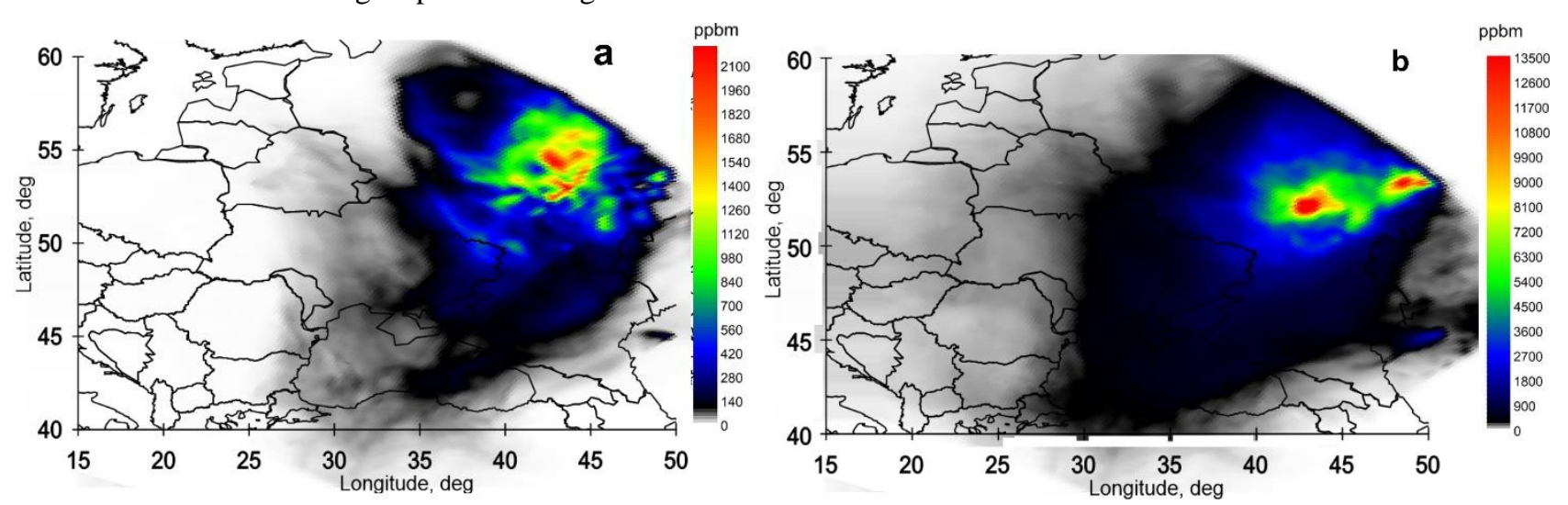

Figure 6: The integral value of the near-surface $\mathrm{BC}$ concentrations for the coarse (a) and accumulation (b) modes for the period 3-18 August 2010.

For the studied period, in general, ground-based dust measurements also showed elevated levels connected with forest fires.

However, analysis of daily averaged values did not give significant results because of high noise level in time series. Proximity of the selected monitoring sites to anthropogenic dust sources in industrial regions and near the roads with intense traffic emissions caused high variability and heterogeneity of obtained daily averaged values. The difference between dust content in August 2010 and other months became more visible when daily values were averaged to monthly ones for all sites within each city.

Almost all geographical regions except northern part of Ukraine have clear maxima of ground-based dust concentrations during August 2010. The highest exceeding over urban background values in August were observed on the eastern territories. Here, the integral value of the near-surface $\mathrm{BC}$ concentrations for the coarse mode was higher than $250 \mathrm{ppbm}$. For the cities on the east, the dust concentrations were 27-47\% higher than average dust content in 2010. Moreover, these were also 23-72\% higher than multi-year average concentrations for month of August. Overall dust content on the east was $0.02-0.07 \mu \mathrm{g} / \mathrm{m} 3$ higher than usually in August. 
Large difference in dust content between August and other months was observed on the seashore of the Azov Sea and in the central part of Ukraine. The concentrations were higher on $0.05-0.25 \mu \mathrm{g} / \mathrm{m} 3$ than usually in the same month. Majority of cities 235 in the central part of Ukraine showed $17-73 \%$ higher dust concentrations than average in 2010 and $8-45 \%$ higher than usually in August.

In the western parts of Ukraine, the integral values were lower than 100 and 500 ppbm for coarse and accumulation modes, respectively (Fig. 6). In these regions the dust concentration difference between August and other months was very low and it $240 \mathrm{did}$ not exceed $0.05 \mu \mathrm{g} / \mathrm{m} 3$. However, dust content in the region is low and differences up to $0.05 \mu \mathrm{g} / \mathrm{m} 3$ correspond to $28-$ $58 \%$ concentration increase over average values.

It should be noted that in addition to the BC atmospheric transport from remote regions (i.e. in particular, due to forest fires occurred outside of Ukrainian territory), local fire emissions could influence levels of near-surface concentrations. During the 245 studied period of elevated pollution episodes in August 2010, there were observed a large number of local fires (Fig. 7). Of course, these could not impact large pollution levels throughout whole boundary layer and the middle troposphere, and moreover, were not transported far from original burned areas. But these fires may influence the total BC deposition and accumulation near the surface layer. The largest area of local fires was observed in the Eastern Ukraine, where burned fraction reached 0.13 (i.e. that on these territories local fires could contribute up to 10-13\%). 


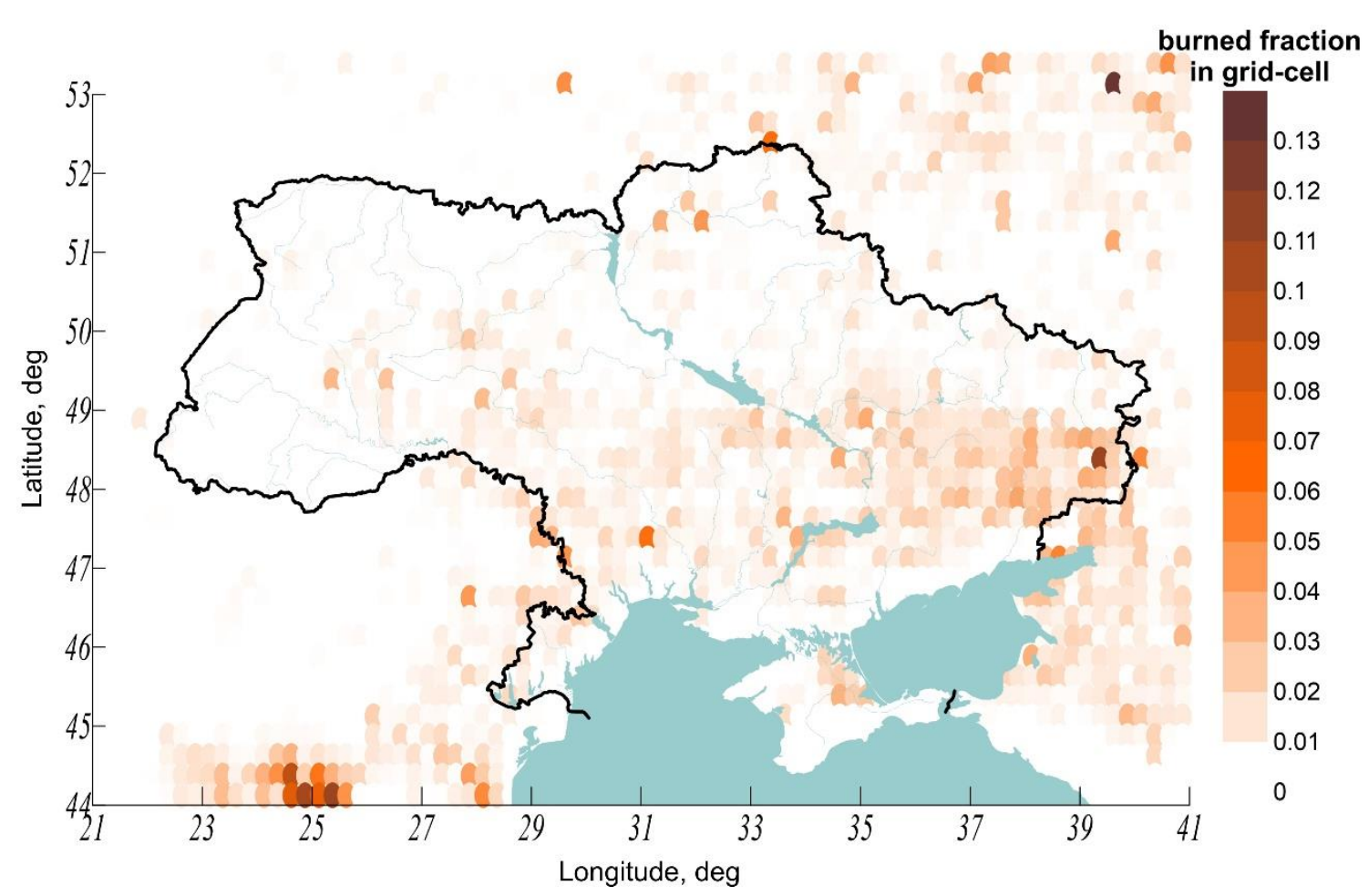

Figure 7: Fingerprint of local fires or burned fraction for August 2010 /derived from $0.25^{\circ} \mathrm{x} 0.25^{\circ}$ grid-cell resolution GFED4 database/.

From the distribution of the near-surface BC concentrations for the coarse mode (Fig. 6) it is seen that there are three "tails" penetrating rather far from the main burning cells into Ukraine. The first one is observed in the north-eastern part, the second - from the eastern to the southern part, and the third is distributed across the Azov and Black Seas. Existence of such "tails" in integrated values could be the result of not only the coincidence with intensification of the $\mathrm{BC}$ atmospheric transport during dominated anticyclonic conditions, but also the impact of local fires with burned fraction more than 0.05 within a grid-cell.

\section{Conclusions}

Employing the Enviro-HIRLAM online integrated modelling system, the patterns of the BC spatio-temporal distribution were estimated for selected elevated pollution period of August 2010 in Ukraine, which resulted from severe forest fires in the central part of Russia. The highest BC content was observed in Ukraine in 2010 during two episodes 7-8 and 13-16 August because of air prevailing movement towards Ukraine from areas/ cells with burning forests. The stationary anticyclone and hence, favourable conditions with deep nighttime air temperature inversions caused constant emission distribution and large accumulative effect in the boundary level. BC was distributed over distances more than $2000 \mathrm{~km}$ from original emission sources. Over Ukraine, it reached 70-150 ppbm for the accumulation mode and 50-80 ppbm for the coarse mode. Vertical 
transport was slower, and particles mainly dispersed in the lowest 3-km layer. However, the fingerprint of BC could be also detected in the middle troposphere (i.e., up to $630 \mathrm{hPa}$ level for the coarse mode and up to $590 \mathrm{hPa}$ for the accumulation mode). The temperature inversions at nights caused diurnal variability of the $\mathrm{BC}$ vertical distribution. Here, concentrations descended to the lower layers at night and ascend at daytime by weakening of downward air movement. For the near-surface level, the integral values over the Eastern Ukraine, Azov Sea and Black Sea territories exceeded 800 and $150 \mathrm{ppbm}$ for the accumulation and coarse modes, respectively. The features of the integral content distribution for the entire studied period and "tails" existence might be influenced also by the $\mathrm{BC}$ emissions from the local sources of fires that observed during these days in the eastern and north-eastern parts of Ukraine.

Code and data availability. The code and data used in this study is available from the authors upon reasonable request.

Author Contributions. MS: Methodology, Investigation, Visualisation, Writing Original and Draft. LP: Investigation, 280 Visualisation, Writing Original and Draft. SK: Conceptualization, Methodology, Supervision. AM: Conceptualization, Methodology, Supervision, Writing - Review and Editing. TP: Writing - Review and Editing. All authors provided comments on manuscript.

Competing Interests. The authors declare that they have no conflict of interests.

Acknowledgements. The study is part of the Enviro-PEEX on ECMWF (Pan-Eurasian EXperiment (PEEX; https://www.atm.helsinki.fi/peex) Modelling Platform research and development for online coupled integrated meteorologychemistry-aerosols feedbacks and interactions in weather, climate and atmospheric composition multi-scale modelling) project (2018-2020).

290 The Enviro-HIRLAM model simulations were performed on the CSC (Center for Science Computing) Sisu HPC (Finland) during the Enviro-HIRLAM/ HARMONIE research training course at the Institute for Atmospheric and Earth System Research (INAR), University of Helsinki (UHEL).

The financial support was provided by the grant within ENVRIplus project for Multi-domain Access to RI platforms "The Influence of Land cover changes On Atmospheric Boundary Layer and Regional Climate Characteristics” (2018).

295 This study was carrying out by the financing of Ukrainian Hydrometeorological Institute within the framework of the State Emergency Service of Ukraine and National Academy of Sciences of Ukraine.

\section{References}

Amiro B.D., Todd J.B., Wotton B.M., Logan K.A., Flannigan M.D., Stocks B.J., Mason J.A., Martell D.L., and Hirsch K.G.:

Direct carbon emissions from Canadian forest fires, 1959-1999., Can. J. For. Res., 31, 512-525, 2001. 
Baklanov, A., Korsholm U.S., Nuterman R., Mahura A., Nielsen K.P., Sass B.H., Rasmussen A., Zakey A., Kaas E., Kurganskiy A., Sørensen B., and González-Aparicio I.: Enviro-HIRLAM online integrated meteorology-chemistry modelling system: strategy, methodology, developments and applications (v7.2)., Geosci. Model Dev., 10, 2971-2999, doi: 10.5194/gmd-10-2971-2017, 2017.

305 Barnaba F., Angelini F., Curci G., and Gobbi G.P.: An important fingerprint of wildfires on the European aerosol load., Atmos. Chem. Phys., 11, 10487-10501, doi: 10.5194/acp-11-10487-2011, 2011.

Bessagnet B., Menut L., Aymoz G., Chepfer H., and Vautard R.: Modeling dust emissions and transport within Europe: The Ukraine March 2007 Event., J. Geophys. Res.-Atmos., Vol. 113, D15202, doi: 10.1029/2007JD009541, 2008.

Bond, T. C., Doherty, S. J., Fahey, D. W., Forster, P. M., Berntsen, T., DeAngelo, B. J., Flanner, M. G., Ghan, S., Kärcher, B.,

310 Koch, D., Kinne, S., Kondo, Y., Quinn, P. K., Sarofim, M. C., Schultz, M. G., Schulz, M., Venkataraman, C., Zhang, H., Zhang, S., Bellouin, N., Guttikunda, S. K., Hopke, P. K., Jacobson, M.Z., Kaiser, J. W., Klimont, Z., Lohmann, U., Schwarz, J. P., Shindell, D., Storelvmo, T., Warren, S. G., and Zender, C. S.: Bounding the role of black carbon in the climate system: A scientific assessment., J. Geophys. Res.-Atmos., 118, 5380-5552, doi:10.1002/jgrd.50171, 2013.

Castagna, J., Senatore, A., Bencardino, M., D’Amore, F., Sprovieri, F., Pirrone, N., and Mendicino, G. Multiscale assessment 315 of the impact on air quality of an intense wildfire season in southern Italy, Sci. Tot. Environ., 761, 143271, doi: 10.1016/j.scitotenv.2020.143271, 2021.

Chubanova N., Nezval, Ye., Sviridenkov I., Smirnov A., and Slutsker I.: Smoke aerosol and its radiative effects during extreme fire event over Central Russia in summer 2010., Atmos. Meas. Tech., 5, 557-568, doi:10.5194/amt-5-557-2012, 2012.

Eleftheriadis K., Vratolis S., and Nyeki S.: Aerosol black carbon in the European Arctic: Measurements at Zeppelin station, Ny-A lesund, Svalbard from 1998-2007., Geophys. Res. Let., 36, L02809, doi: 10.1029/2008GL035741, 2009.

Forbes, M., Raison R.J., and Skjemstad J.O.: Formation, transformation and transport of black carbon (charcoal) in terrestrial and aquatic ecosystems., Sci Total Environ., 370(1), 190-206, doi: 10.1016/j.scitotenv.2006.06.007, 2000.

Galytska E., Danylevsky V., Hommel R., and Burrows J.P.: Increased aerosol content in the atmosphere over Ukraine during summer 2010., Atmos. Meas. Tech., 11, 2101-2118, doi: 10.5194/amt-11-2101-2018, 2018.

325 Galytska E., Danylevsky V., and Snizhko S.: Aerosols dynamics in the atmosphere over Eastern Europe by means of AERONET according to weather conditions during summer 2010., Ukr. gìdrometeorol. ž., 17, 5-16, doi: 10.31481/uhmj.17.2016.01, 2016.

Giglio, L., Randerson, J. T. and van der werf, G. R.: Analysis of daily, monthly, and annual burned area using the fourthgeneration global fire emissions database (GFED4)., J. Geophys. Res.-Biogeos., 118(1), 317-328, doi: 10.1002/jgrg.20042, 2013.

HIRLAM-5 Scientific Documentation, Per Unden, December 2002.

Hodzic, A., Madronich, S., Bohn, B., Massie, S., Menut, L., and Wiedinmyer, C.: Wildfire particulate matter in Europe during summer 2003: meso-scale modeling of smoke emissions, transport and radiative effects., Atmos. Chem. Phys., 7, 4043-4064, doi:10.5194/acp-7-4043-2007, 2007. 
Janssen N.A., Hoek G, Simic-Lawson M., Fischer P., van Bree L., ten Brink H., Keuken M., Atkinson R.W., Anderson H.R., Brunekreef B., and Cassee F.R.: Black carbon as an additional indicator of the adverse health effects of airborne particles compared to PM10 and PM2.5., Environ Health Perspect; 119(12), 1691-9, doi: 10.1289/ehp.1003369, 2011.

Jia, M., Evangeliou, S., Eckhardt, S., Huang, X., Gao, J., Ding, A., and Stohl, A. Black Carbon Emission Reduction Due to COVID-19 Lockdown in China. Geophysical Research Letters, 48, e2021GL093243, doi: 10.1029/2021GL093243, 2021.

340 Konovalov I.B., Beekmann M., Kuznetsova I.N., Yurova A., and Zvyagintsev A.M.: Atmospheric impacts of the 2010 Russian wildfires: integrating modelling and measurements of an extreme air pollution episode in the Moscow region. Atmos. Chem. Phys., 11, 10031-10056, doi: 10.5194/acp-11-10031-2011, 2011.

Konovalov I.B., Lvova D.A., Beekmann M., Jethva H., Mikhailov E.F., Paris J.-D., Belan B.D., Kozlov V.S., Ciais P., and Andreae M.O.: Estimation of black carbon emissions from Siberian fires using satellite observations of absorption and extinction optical depths. Atmos. Chem. Phys., 18, 14889-14924, doi: 10.5194/acp-18-14889-2018, 2018.

Kostrykin, S., Revokatova, A., Chernenkov, A., Ginzburg, V., Polumieva, P., and Zelenova, M. Black Carbon Emissions from the Siberian Fires 2019: Modelling of the Atmospheric Transport and Possible Impact on the Radiation Balance in the Arctic Region., Atmosphere, 12(7), 814, doi: 10.3390/atmos12070814, 2021.

Kurganskiy A., Nuterman R.B., Mahura A.G., Baklanov A.A., Sass B.H., and Kaas E. Enviro-HIRLAM black carbon modelling for Northern Europe and Arctic. Climate Change for Arctic Seas and Shipping: 3rd CRAICC-PEEX Workshop, 2425 August 2015, Copenhagen, Denmark, Danish Meteorological Institute: programme and abstracts. P. 14, 2015.

Leino, K., Riuttanen, L., Nieminen, T., Dal Maso, M., Väänänen, R., Pohja, T., Keronen, P., Järvi, L., Aalto, P.P., Virkkula, A., Kerminen, V.-M., Petäjä, T. and Kulmala, M. Biomass-buring smoke episodes in Finland from Eastern European wildfires, Boreal Environ Res. 19 B, 275-292, 2014.

355 Magalhaes, N.d., Evangelista, H., Condom, T., Rabatel, A., and Ginot, P. Amazonian Biomass Burning Enhances Tropical Andean Glaciers Melting. Sci Rep., 9, 16914, doi: 10.1038/s41598-019-53284-1, 2019

Nadtochii L.M., Savenets M.V., Bashtannik M.P., and Dvoretska I.V.: The features of dust air pollution dynamics in certain Ukrainian cities. Ukr. geogr. z., 1, 43-50, doi: 10.15407/ugz2019.01.043, 2019.

Nuterman, R., Mahura, A., Baklanov, A., Kurganskiy, A., Amstrup, B., and Kaas, E.: Enviro-HIRLAM Applicability for Black 360 Carbon Studies in Arctic., Geophysical Research Abstracts, 17, EGU2015-1571, 2015.

O’Dell, K., Hornbrook, R.S., Permar, W., Levin, E., Garofalo, L.A., Apel, E.C., Blake, N.J., Jarnot, A., Pothier, M.A., Farmer, D.K., Lu Hu, Campos, T., Ford, B., Pierce, J.R., and Fischer, E.V. Hazardous Air Pollutants in Fresh and Aged Western US Wildfire Smoke and Implications for Long-Term Exposure, Environ. Sci. Technol., 54, 11838-11847, doi: 10.1021/acs.est.0c04497, 2020.

365 Pavese G., Calvello M., and Esposito F.: Black Carbon and Organic Components in the Atmosphere of Southern Italy: Comparing Emissions from Different Sources and Production Processes of Carbonaceous Particles., Aerosol and Air Quality Research, 12, 1146-1156, doi: 10.4209/aaqr.2011.12.0236, 2012. 
Pere J.C., Bessagnet B., Mallet M., Waquet F., Chiapello I., Minvielle F., Pont V., and Menut L.: Direct radiative effect of the Russian wildfires and its impact on air temperature and atmospheric dynamics during August 2010. Atmos. Chem. Phys., 14, 1999-2013, doi: 10.5194/acp-14-1999-2014, 2014.

Singh, R.P., Kumar, S., and Singh, A.K. Elevated Black Carbon Concentrations and Atmospheric Pollution around Singrauli Coal-Fired Thermal Power Plants (India) Using Ground and Satellite Data. Int. J. Environ. Res. Public Health, 15(11), 2472, doi: 10.3390\%2Fijerph15112472, 2018.

WHO Report. Health effects of black carbon. 2012. http://www.euro.who.int/data/assets/pdf_file/0004/162535/e96541.pdf

375 Witte J.H., Douglass A.R., da Silva A., Torres O., Levy R., and Duncan B.N.: NASA A-Train and Terra observations of the 2010 Russian wildfires., Atmos. Chem. Phys., 11, 9287-9301, doi: 10.5194/acp-11-9287-2011, 2011.

Upper Air Soundings. Wyoming University: http://weather.uwyo.edu/upperair/sounding.html Yang Yang, Hailong Wang, Steven J. Smith, Po-Lun Ma and Philip J. Rasch.: Source attribution of black carbon and its direct radiative forcing in China. Atmos. Chem. Phys., 17, 4319-4336, doi: 10.5194/acp-17-4319-2017, 2017.

Virkkula, A., Pohja, T., Aalto, P.P., Keronen, P., Schobesberger, S., Clements, C.B., Petäjä, T., Nikmo, J. and Kulmala, M. Airborne measurements of aerosols and carbon dioxide during a prescribed fire experiment at a boreal forest site, Boreal Environ. Res., 19 B, 153-181, 2014a.

Virkkula, A., Levula, J., Pohja, T., Aalto, P.P., Keronen, P., Schobesberger, S., Clements, C.B., Pirjola, L., Kieloaho, A.-J., Kulmala, L., Aaltonen, H., Patokoski, J., Pumpanen, J., Rinne, J., Ruuskanen, T., Pihlatie, M., Manninen, H.E., Aaltonen, V., Junninen, H., Petäjä, T., Backman, J., Dal Maso, M., Nieminen, T., Olsson, T., Grönholm, T., Aalto, J., Virtanen, T.H., Kajos, M., Kerminen, V.-M., Schultz, D.M., Kukkonen, J., Sofiev, M., De Leeuw, G., Bäck, J., Hari, P. and Kulmala, M. Prescribed burning of logging slash in the boreal forest in Finland: emissions and effects on meteorological quantities and soil properties, Atmos. Chem. Phys., 14, 4473-4502, doi: 10.5194/acp-14-4473-2014, 2014.

Wu, Y., Anjeza, A., Jianping, H., Barry, G., and Fred, M. Intra-continental wildfire smoke transport and impact on local air quality observed by ground-based and satellite remote sensing in New York City, Atmos. Environ. 187, 266-281, doi: 10.1016/j.atmosenv.2018.06.006, 2018.

Yttri K. E., Aas W., Bjerke A., Cape J. N., Cavalli F., Ceburnis D., Dye C., Emblico L., Facchini M. C., Forster C., Hanssen J. E., Hansson H. C., Jennings S. G., Maenhaut W., Putaud J. P., and Torseth K.: Elemental and organic carbon in PM10: a one year measurement campaign within the European Monitoring and Evaluation Program EMEP, Atmos. Chem. Phys., 7, 5711-5725, doi: 10.5194/acp-7-5711-2007, 2007. 